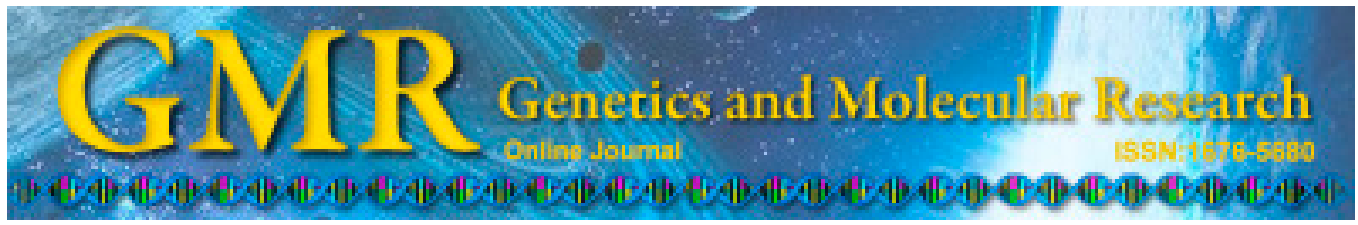

\title{
Isolation and characterization of polymorphic microsatellite loci in the sea cucumber Holothuria scabra
}

\author{
Z.B. Li ${ }^{1,2}$, G. Dai ${ }^{1,2}$, J.B. Shangguan ${ }^{1,2}$, Y.F. Ning ${ }^{1,2}, Y . Y$. Li $^{1,2}$, R.B. Chen ${ }^{1,2}$, \\ Y.S. Huang ${ }^{1,2}$ and Y. Yuan ${ }^{1,2}$ \\ ${ }^{1}$ Fisheries College, Jimei University, Xiamen, China \\ ${ }^{2}$ Fujian Provincial Key Laboratory of Marine Fishery Resources and \\ Eco-environment, Xiamen, China \\ Corresponding author: Z.B. Li \\ E-mail: lizhongbao@jmu.edu.cn
}

Genet. Mol. Res. 14 (2): 6529-6532 (2015)

Received August 7, 2014

Accepted January 23, 2015

Published June 12, 2015

DOI http://dx.doi.org/10.4238/2015.June.12.5

\begin{abstract}
The sea cucumber Holothuria scabra is an endangered species. In this study, nine new polymorphic microsatellite loci were developed and tested in 30 individuals. The number of alleles ranged from 2 to 5 , and the observed and expected heterozygosities ranged from 0.1200 to 0.7391 and from 0.2408 to 0.5983 , respectively. No loci significantly deviated from the Hardy-Weinberg equilibrium after a Bonferroni correction, and no significant linkage disequilibrium was found between pairs of loci. These polymorphic microsatellite loci will be useful in studying the genetic diversity of $H$. scabra and its conservation.
\end{abstract}

Key words: Sea cucumber; Holothuria scabra; Microsatellite; Conservation 


\section{INTRODUCTION}

Holothurians, commonly known as sea cucumbers, have been a dietary delicacy and medicine in Asia for several centuries (Toral-Granda et al., 2008). Holothuria scabra is one such sea cucumber, and is widely distributed in shallow, soft-bottom habitats throughout the Indo-Pacific. It is the only tropical Holothurian species that can be mass-produced in hatcheries. However, because of commercial exploitation, natural stocks of $H$. scabra have decreased throughout their geographic range (Hamel et al., 2001), and it is listed as 'Endangered' on the IUCN Red List (Hilton-Taylor and Mittermeier, 2000). Microsatellites, repeating sequences of 1-6 base pairs of DNA, are considered powerful genetic and molecular markers due to their abundance in the genome and their high frequency of polymorphisms (Bruford and Wayne, 1993). Although 18 polymorphic microsatellite loci have been identified in $H$. scabra (Fitch et al., 2013), further microsatellite loci should be developed in order to investigate the species' population structure.

\section{MATERIAL AND METHODS}

Nine polymorphic microsatellite loci were developed following the fast isolation by amplified fragment length polymorphism of sequences containing repeats according to the FIASCO method (Zane et al., 2002). Genetic DNA was extracted from tube-foot tissues using a Genomic DNA Extraction Kit (Tiangen, China). The DNA was digested using the restriction enzyme MseI (Fermentas, Lithuania) for $3.5 \mathrm{~h}$ at $65^{\circ} \mathrm{C}$, and the digested fragments were ligated to $M s e$ I adaptor A (5'-GACGATGAGTCCTGAG-3')/MseI adaptor B (5'-TACTCAGGA CTCAT-3') using T4 DNA ligase (Fermentas, Lithuania) overnight at $22^{\circ} \mathrm{C}$. The ligated fragments were hybridized to the biotinylated probes $(\mathrm{CT})_{15}$ and $(\mathrm{GT})_{15}$, and captured by streptavidin-coated magnetic sphere particles (Promega, USA). The recovered DNA fragments were amplified using an MseI primer (5'-GACGATGAGTCCTGAG-3') and purified using a GenClean Cycle Pure Kit (Omega Bio-Tek, USA) to remove extra adaptors and deoxynucleotide triphosphate (dNTPs). The purified products were ligated with a pMD19-T vector (Takara, Japan), and transformed into the Escherichia coli-competent cells, DH5 $\alpha$ (Tiangen, China). The transformants were selected on lysogeny broth agar plates containing ampicillin. Recombinant clones were amplified using universal M13 primers, and the polymerase chain reaction (PCR) products were visualized on $1 \%$ agarose gels. One hundred and fifty-nine positive clones that were 500 to $1000 \mathrm{bp}$ in length were selected for sequencing by Major Bio (Shanghai, China), and 34 pairs of primers were designed by Primer Premier 5.0.

All 34 pairs of primers were validated in 30 individuals of $H$. scabra that had been collected from Hainan Island, China. PCR amplification was performed in a $10-\mu \mathrm{L}$ reaction volume containing $50 \mathrm{ng}$ of genomic DNA, 10X Dream Taq buffer $(2 \mathrm{mM} \mathrm{MgCl}), 0.25 \mathrm{U}$ Dream Taq DNA Polymerase (ThermoFisher Scientific, USA), $0.2 \mathrm{mM}$ dNTP, and $0.4 \mu \mathrm{M}$ of primer, using a peqSTAR thermal cycler (Peqlab, Germany). The PCR was carried out under the following conditions: $95^{\circ} \mathrm{C}$ for $5 \mathrm{~min}, 32$ cycles at $95^{\circ} \mathrm{C}$ for $40 \mathrm{~s}$, at the annealing temperature (Table 1) for $40 \mathrm{~s}, 72^{\circ} \mathrm{C}$ for $1 \mathrm{~min}, 72^{\circ} \mathrm{C}$ for $10 \mathrm{~min}$, and then stored at $4^{\circ} \mathrm{C}$. The amplified products were resolved on $6 \%$ denaturing polyacrylamide gels using a Sequi-Gen ${ }^{\circledR}$ Sequencing Cell (Bio-Rad, USA).

The number of alleles per locus $\left(N_{\mathrm{A}}\right)$, the polymorphic information content (PIC), and the observed $\left(H_{\mathrm{O}}\right)$ and expected $\left(H_{\mathrm{E}}\right)$ heterozygosities were calculated using the POP- 
GEN 32 (version 1.32) and the CERVUS 3.0 (version 2.2.3) software. Deviations from the Hardy-Weinberg equilibrium (HWE) and genotypic linkage disequilibrium were tested using POPGENE 32 (version 1.32).

\section{RESULTS AND DISCUSSION}

We successfully amplified nine polymorphic loci (Table 1 ). The $N_{\mathrm{A}}$ ranged from 2 to 5, and the PIC ranged from 0.402 to 0.670 . The $H_{\mathrm{O}}$ and $H_{\mathrm{E}}$ ranged from 0.1200 to 0.7391 and from 0.2408 to 0.5983 , respectively. No significant linkage disequilibrium was detected for any pairwise combination of loci. All of the loci were at HWE after sequential Bonferroni corrections $(\mathrm{P}>0.00556)$. The novel microsatellite loci identified in the present study will be useful in studying the genetic diversity and population structure of this species, and in designing an effective conservation strategy for it.

\section{Table 1. Nine polymorphic microsatellite loci in Holothuria scabra.}

\begin{tabular}{|c|c|c|c|c|c|c|c|c|c|}
\hline Locus ID & GenBank & Primer sequence (5'-3') & Repeat motif & $\mathrm{Ta}\left({ }^{\circ} \mathrm{C}\right)$ & Allele size (bp) & $N_{\mathrm{A}}$ & PIC & $H_{\mathrm{O}}$ & $H_{\mathrm{E}}$ \\
\hline \multirow[t]{2}{*}{ CHS1-17 } & KJ875899 & SCCGACTTGTCTTCATTCC & & & & & & & \\
\hline & & $\mathrm{R}: \mathrm{CCT}$ & $(\mathrm{AC})_{42}$ & 42 & $148-154$ & 3 & 0.554 & 0.6364 & 0.4339 \\
\hline \multirow[t]{2}{*}{ CHS1-22 } & KJ875900 & F: CTGCGAGAAGCGACCTGT & & & & & & & \\
\hline & & R: TCTTCACTGTCCACC & $(\mathrm{GT})_{16}$ & 45 & $130-134$ & 2 & 0.402 & 0.1200 & 0.2408 \\
\hline \multirow[t]{2}{*}{ CHS1-30 } & KJ875901 & F: TTGACCGAGTGTG & & & & & & & \\
\hline & & $\mathrm{R}: \mathrm{CT}$ & $(\mathrm{AC})_{15}$ & 45 & $86-92$ & 3 & 0.499 & 0.3810 & 0.3084 \\
\hline \multirow[t]{2}{*}{ CHS2-1 } & KJ875902 & $\mathrm{F}: \mathrm{AAC}$ & & & & & & & \\
\hline & KI87 & R: GAC & $(\mathrm{GACAAG})_{3}$ & 49 & $152-154$ & 3 & 0.514 & 0.5769 & 0.4815 \\
\hline CHS2-13 & & R: GGA & $(\mathrm{AG}$ & 45 & $192-206$ & 3 & 0.568 & 0.4545 & 0.4628 \\
\hline \multirow[t]{2}{*}{ CHS2-18 } & KJ875904 & F: CAGACGGGAACATCACCA & & & & & & & \\
\hline & & R: CCGCACCTGACACT & $(\mathrm{GACAAG})_{4}$ & 49 & $148-156$ & 5 & 0.670 & 0.7391 & 0.5983 \\
\hline CHS3-11 & КJo/J900 & R: CACGCACTGTCATACTCCAC & $(\mathrm{CA})_{31} \mathrm{~N}(\mathrm{CA})_{29}$ & 42 & 8 & 4 & 0.554 & 0.5600 & 0.4224 \\
\hline \multirow[t]{2}{*}{ CHS3-67 } & KJ875907 & $\begin{array}{l}\text { R: AGGGGTCTGGAGGAGGTTCT } \\
\text { F: ACCCGAGCGAAGATTAGT }\end{array}$ & $(\mathrm{CA})_{11} \mathrm{~N}(\mathrm{GAA})_{4}$ & 42 & $110-114$ & 3 & 0 & 6000 & 38 \\
\hline & & R: CGAAAGTTCATCGTGTCC & $(\mathrm{GCAA})_{3}$ & 57 & $178-184$ & 2 & 0.456 & 0.2857 & 0.4898 \\
\hline
\end{tabular}

Ta, Annealing temperature; bp; PIC, polymorphism information content; $N_{\mathrm{A}}$, number of alleles per locus; $H_{\mathrm{O}}$, observed heterozygosity; $H_{\mathrm{E}}$, expected heterozygosity.

\section{ACKNOWLEDGMENTS}

Research supported by the Natural Science Foundation of Fujian Province (\#2011J01231), the National Natural Science Foundation of China (\#31272668), the Program for New Century Excellent Talents in Fujian Province University, and the Foundation for Innovative Research Team of Jimei University, China (\#2010A004).

\section{REFERENCES}

Bruford MW and Wayne RK (1993). Microsatellites and their application to population genetic studies. Curr. Opin. Genet. Dev. 3: 939-943.

Fitch AJ, Leeworthy G, Li X, Bowman W, et al. (2013). Isolation and characterization of eighteen microsatellite markers from the sea cucumber Holothuria scabra (Echinodermata: Holothuriidae). Aust. J. Zool. 60: 368-371.

Hamel J-F, Conand C, Pawson DL and Mercier A (2001). The sea cucumber Holothuria scabra (Holothuroidea: Echinodermata): its biology and exploitation as Beche-de-mer. Adv. Mar. Biol. 41: 129-223. 
Hilton-Taylor C and Mittermeier RA (2000). 2000 IUCN red list of threatened species. IUCN, Switzerland.

Toral-Granda V, Lovatelli A and Vasconcellos M (2008). Sea cucumbers: a global review of fisheries and trade. Food and Agric. Organ. United Nations.

Zane L, Bargelloni L and Patarnello T (2002). Strategies for microsatellite isolation: a review. Mol. Ecol. 11: 1-16. doi: 10.1.46/j.0962-1083.2001.01418.x 